\author{
KATARZYNA KAJKA*, BEATA RUTKOWSKA \\ Warsaw University of Life Sciences, Department of Soil Environment Sciences, Division of Agricultural Chemistry \\ 159 Nowoursynowska Str., 02-776 Warsaw, Poland
}

\title{
Accumulation of selected heavy metals in soils and common dandelion (Taraxacum officinale) near a road with high traffic intensity
}

\begin{abstract}
The aim of the study was to determine the levels of selected trace elements in soils and in the common dandelion depending on the distance from a traffic route. The study was conducted in Warsaw near one of the main roads in the suburb of Ursynów. Samples for testing were taken from the 0-25 cm layer at sites located directly alongside the roadway and at a distance of 30,60 and $300 \mathrm{~m}$ from its edge. The amounts of $\mathrm{Pb}, \mathrm{Ni}, \mathrm{Cu}, \mathrm{Zn}$ and $\mathrm{Cd}$ in the soils were determined by the AAS method, after extraction in $\mathrm{HCl}$ at a concentration of $1 \mathrm{~mol} \cdot \mathrm{dm}^{-3}$, and in the aboveground parts and roots of dandelion plants after wet mineralization in a mixture of $\mathrm{HNO}_{3}$ and $\mathrm{HClO}_{4}$ by the AAS method. On the basis of the results obtained, it was shown that the concentrations of the tested metals, both in the soils and in the biomass of the test plant, were highest directly at the edge of the roadway and decreased significantly with the distance away from the road. This correlation indicates a significant impact of road transport on heavy metal levels in the environment bordering a traffic route. It was also shown that dandelion plants accumulate higher amounts of heavy metals in the aboveground parts than in the roots, and the heavy metal contents in the dandelion biomass were found to be significantly positively correlated with the amounts of these elements in the soils.
\end{abstract}

Keywords: trace elements, road transport, urban soils, road vegetation, soil contamination

\section{INTRODUCTION}

The dynamic development of transport, economy and industry has contributed to negative changes in the natural environment. Traffic routes are a source of emissions of harmful gases, aerosols and dusts containing heavy metals released in the processes of fuel combustion and abrasion of asphalt surfaces and the wearing of vehicle parts (Athanasopoulou and Kollaros 2016). The problem of heavy metal soil pollution originating from road traffic occurs in the vicinity of busy thoroughfares in large suburbs, where a very large number of vehicles move in relatively small areas, and where congested traffic contributes to high exhaust emissions (Wei and Yang 2010).

The heavy metals accumulated in the soil constitute a potential reservoir of elements that plants absorb, which poses a threat to the entire trophic chain. The disruption of the natural environmental balance results in a deterioration in life quality of living organisms, including humans, leading to the emergence of diseases including cancerous changes (Kaszubkiewicz and Kawałko 2009).
Due to the people's growing awareness of the state of the natural environment, there have been noticeable, environmentally friendly, changes in technologies used. For example, permissible levels of selected pollutants in the soil are being introduced (Karczewska and Kabała 2017). Examination of the effects on polluted ecosystems or those potentially exposed to these adverse changes, and activities leading to their regeneration, are also becoming a priority. The process of subjecting polluted areas to the procedures of reducing the content of harmful substances begins with measuring pollution. The methods that serve to determine the degree of pollution include bioindication methods based on the use of phytoindicators and pedoindicators (Świercz 2004). The common dandelion is a typical example of a phytoindicator, because it is common in most habitats and is characterized by high tolerance to chemical contamination. The plant shows variability in accumulation between the parts above and under the ground, which makes it possible to visualize the migration of heavy metals in plant organs (Bomze et al. 2007). 
The aim of the study was to determine the effect of distance from a busy urban road on soil heavy metal content and in particular parts of the common dandelion.

\section{MATERIALS AND METHODS}

The study was conducted at a section of the road called Aleja Jana Rodowicza 'Anody' in the Warsaw suburb of Ursynów. The road is a dual carriageway divided by a green strip with a pavement for pedestrians and a cycle path. The daily traffic on this carriageway is estimated at approx. 37,500 vehicles (website 1). The total length of the traffic route is $1.3 \mathrm{~km}$.

Soil samples for analyses were collected in May 2016 along a $500 \mathrm{~m}$-long carriageway section adjacent to the Warsaw University of Life Sciences (SGGW) campus. The soil samples were taken from the $0-25 \mathrm{~cm}$ layer using Egner's sampling probe. The samples were collected directly at the edge of the roadway, from the green strip between the roadways (samples 1-5), and from a distance of $30 \mathrm{~m}$ from the edge of the roadway (samples 6-8) and $60 \mathrm{~m}$ from the roadway (samples 11-14), as well as from one control point located $300 \mathrm{~m}$ from the traffic route (sample No. 16) located on the SGGW campus (Figure 1, website 2). The soil material at each measuring point was collected in two replications.

The collected soil samples were dried and sieved through a 2-mm sieve. The prepared samples were analyzed to determine: soil $\mathrm{pH}$ in a solution of $1 \mathrm{~mol}$ $\mathrm{KCl} \cdot \mathrm{dm}^{-3}$ using the potentiometric method and the content of selected trace elements, i.e. nickel, copper, zinc, cadmium and lead, by atomic absorption spectrometry after extraction in $1 \mathrm{~mol} \mathrm{HCl} \cdot \mathrm{dm}^{-3}$.

Plants of the common dandelion (Taraxacum officinale) were collected from the same locations from which soil samples were collected. Plants were collected in three replications from each measuring

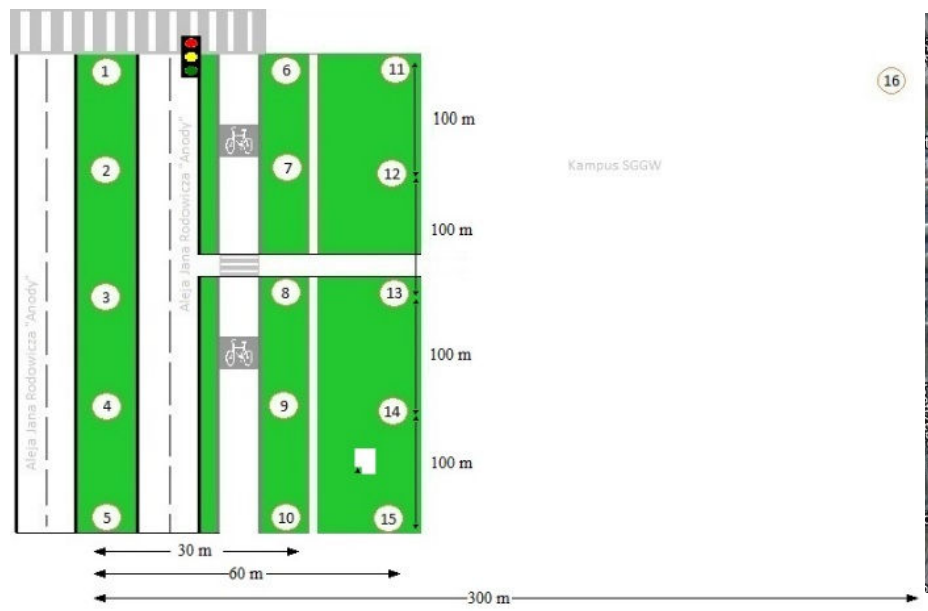

FIGURE 1. Localization of measurement points point. All of the collected plants were at the same post-flowering stage of development. The collected plants were washed with tap water and distilled water, and then divided into the aboveground parts and roots, dried in a drier and ground up with a grinder. The prepared material was subjected to mineralization in a mixture of concentrated acids: nitric (V) acid $\mathrm{HNO}_{3}$ and chloric (VII) acid $-\mathrm{HClO}_{4}$ mixed at a $4: 1$ ratio. After mineralization, the solution was analyzed, like the soil samples, to determine the amounts of $\mathrm{Ni}$, $\mathrm{Cu}, \mathrm{Zn}, \mathrm{Cd}$ and $\mathrm{Pb}$ by atomic absorption spectrometry.

The results for the amounts of heavy metals in soil and plants were statistically analyzed using the univariate variance analysis method. To assess the significance of the mean differences, the Tuckey test was used at a significance level of $p=0.05$. At the same time, linear regression analysis was performed between the amounts of the metals estimated in the roots and aboveground parts of dandelion plants and the amounts of these elements in the soil. All calculations were made using the Statistica ver. 10.0 programme.

\section{RESULTS AND DISCUSSION}

Irrespective of the location from which samples were taken for analysis, the studied soils were alkaline (Table 1). The highest $\mathrm{pH}$ value (7.6) was shown for the soil located at the greatest distance from the edge of the roadway. The soil alkalization in cities is mainly related to the deposition of alkaline materials as dusts and the use of agents for de-icing the roadways (Sławiński et al., 2014).

Among the estimated heavy metals, zinc was present in the soils in the largest amounts (from 8.03 to 27.00 $\mathrm{mg} \cdot \mathrm{kg}^{-1}$ ), and cadmium in the smallest amounts (from 0.05 to $\left.0.20 \mathrm{mg} \cdot \mathrm{kg}^{-1}\right)$. The series of decreasing metal content in the soil was as follows: $\mathrm{Zn}>\mathrm{Pb}>\mathrm{Cu}>\mathrm{Ni}>\mathrm{Cd}$ (Table 1). The highest concentrations of heavy

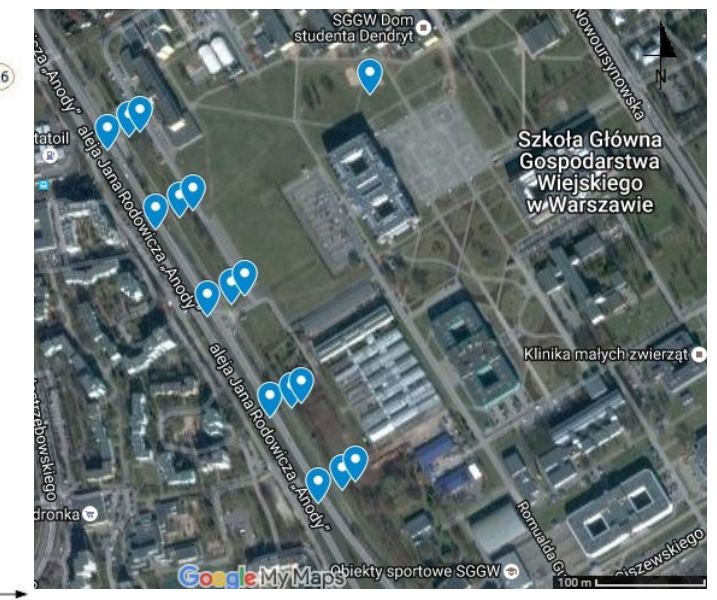

(website 2) 
TABLE 1. The soil $\mathrm{pH}$ and contents of heavy metals in the studied soils values marked with the same letters do not differ significantly according to Tuckey test in $p=0.05$

\begin{tabular}{|c|c|c|c|c|c|c|}
\hline \multirow{2}{*}{$\begin{array}{l}\text { Distance } \\
\text { from the } \\
\text { roadway } \\
\text { [m] }\end{array}$} & \multirow{2}{*}{$\begin{array}{l}\mathrm{pH} \\
\left(\mathrm{H}_{2} \mathrm{O}\right)\end{array}$} & $\mathrm{Zn}$ & $\mathrm{Cd}$ & $\mathrm{Cu}$ & $\mathrm{Ni}$ & \multirow[t]{2}{*}{$\mathrm{Pb}$} \\
\hline & & \multicolumn{4}{|c|}{$\left[\mathrm{mg} \cdot \mathrm{kg}^{-1}\right]$} & \\
\hline 0 & 7.3 & $27.0 \mathrm{~d}$ & $0.20 \mathrm{c}$ & $10.2 \mathrm{~d}$ & $1.63 \mathrm{bc}$ & $29.3 \mathrm{c}$ \\
\hline 30 & 7.3 & $16.4 \mathrm{c}$ & $0.08 \mathrm{~b}$ & $5.06 \mathrm{c}$ & $1.85 \mathrm{c}$ & $8.31 \mathrm{~b}$ \\
\hline 60 & 7.2 & $10.7 \mathrm{~b}$ & $0.08 b$ & $3.87 \mathrm{~b}$ & $1.53 \mathrm{~b}$ & $8.81 \mathrm{~b}$ \\
\hline 300 & 7.6 & $8.03 \mathrm{a}$ & $0.05 \mathrm{a}$ & $3.11 \mathrm{a}$ & $0.83 \mathrm{a}$ & $4.31 \mathrm{a}$ \\
\hline
\end{tabular}
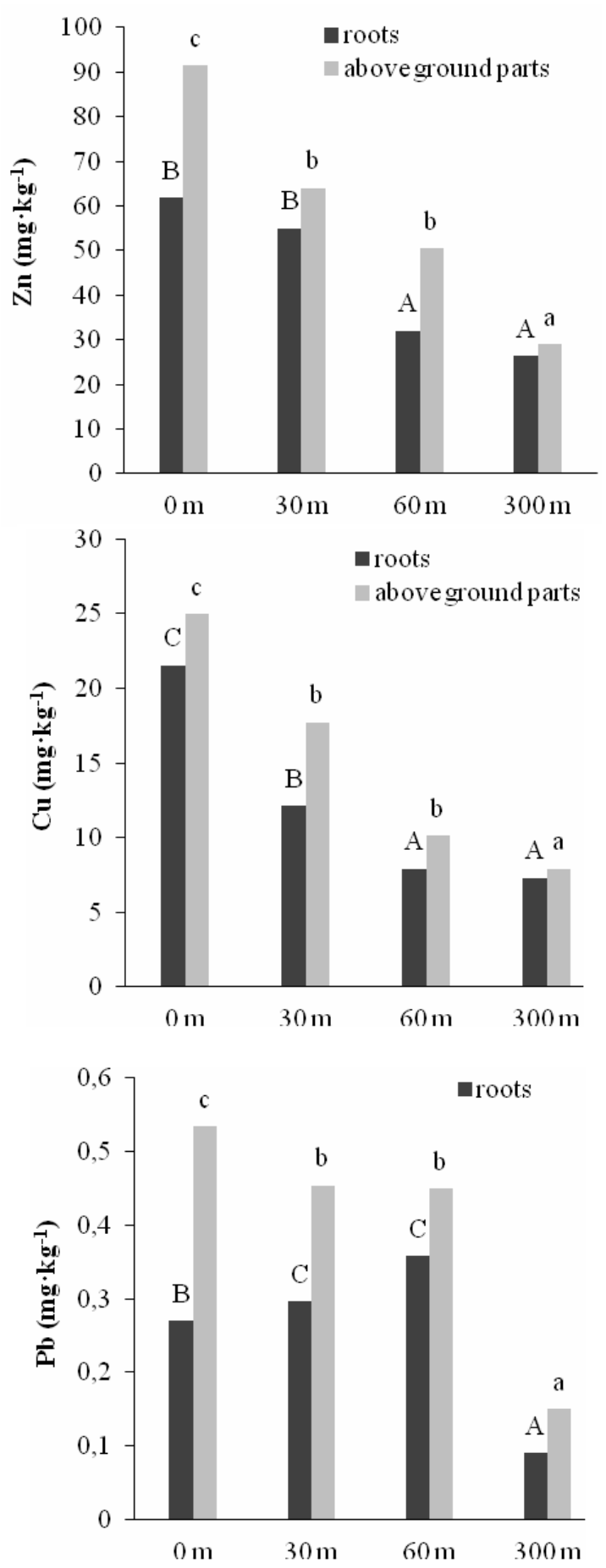

metals were determined in the soil in the immediate vicinity of the roadway, and they decreased significantly with the distance from its edge (Table 2). At a distance of $300 \mathrm{~m}$ from the roadway, the amounts of estimated metals were from two (for Ni) to seven (for $\mathrm{Pb}$ ) times smaller than in the immediate proximity of the roadway. In their studies on the effect of traffic pollution on the heavy metal content in the soils of Warsaw, other authors have also observed a tendency for the levels of these elements in the soils to decrease with the increase in the distance from the traffic route
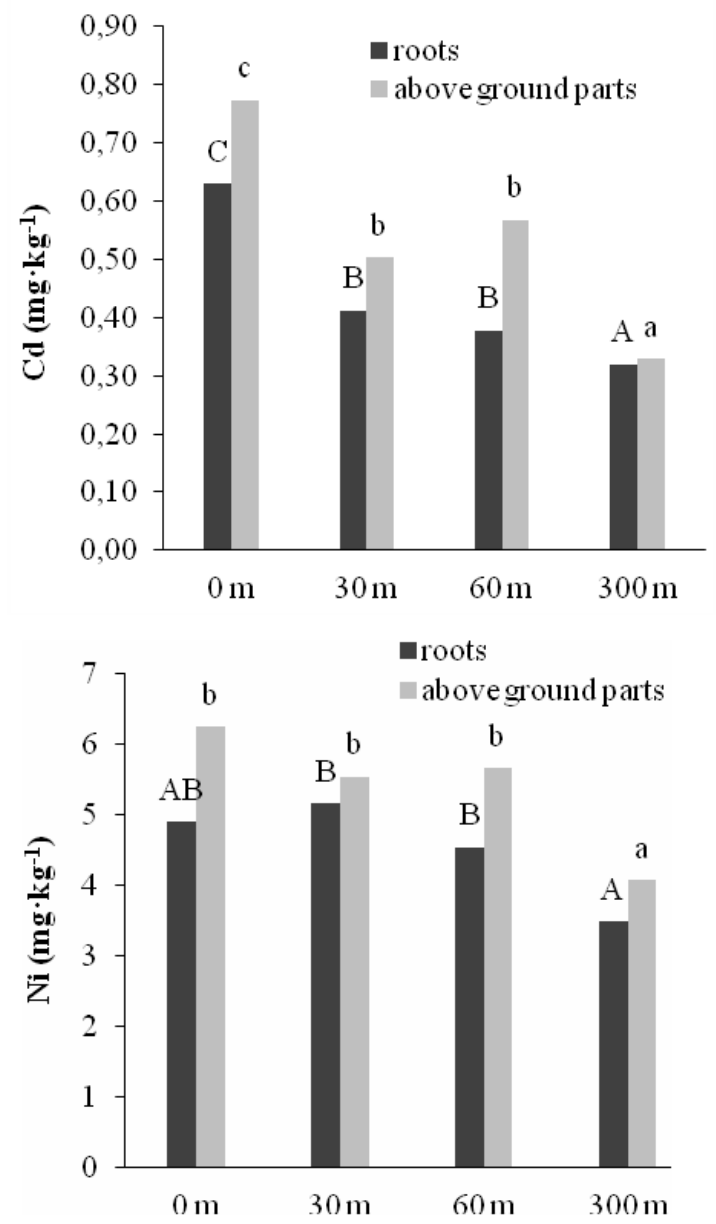

FIGURE 2. Common dandelion heavy metal biomass contents in relation to distance from the road: values marked with the same letters do not differ significantly according to Tuckey test, at $p=$ 0.05 ; in capital letters A, B, C-homogeneous groups for the root metal content were marked; in small letters a, b, c, - homogeneous groups for the content of metals in parts above ground were marked

(Czarnowska 1999, Niesiobędzka and Krajewska 2008, Czubaszek and Bartoszuk 2011, Dmochowski et al. 2011, Dzierżanowski and Gawroński 2011, Komorowski and Szulc 2017, Kowalczyk and Szulc 2017). The threats posed by the heavy metals emitted by motor vehicles depend on: traffic intensity, distance from the road, and the topography of the land and the 
manner of its utilization (Dmochowski et al. 2011). As shown by Athanasopoulou and Kollaros (2016), the width of the zone affected by traffic pollution is limited to about $50 \mathrm{~m}$ on both sides of the road.

As in the case of the soil, the concentrations of metals in dandelion plants were the highest in the immediate vicinity of the roadway and decreased with the distance from its edge (Figure 2). Only in the case of lead content in the dandelion roots was an inverse tendency observed. The concentration of this element in the roots increased from $0.27 \mathrm{mg} \cdot \mathrm{kg}^{-1}$ in the immediate proximity of the roadway to $0.36 \mathrm{mg} \cdot \mathrm{kg}^{-1}$ at a distance of $60 \mathrm{~m}$ from the edge of the roadway, and then it decreased to a value of $0.09 \mathrm{mg} \cdot \mathrm{kg}^{-1}$ at a distance of $300 \mathrm{~m}$ from the edge of the roadway. A similar increase in the lead content of dandelion roots at a distance of $50 \mathrm{~m}$ from the road was obtained by Jankowska et al. (2007).

It was shown that regardless of the sampling location, higher concentrations of the estimated metals were found in the dandelion plant parts above the ground than in the roots. Among the metals analyzed, zinc was present in the highest amounts (from 26.3 to 61.8 $\mathrm{mg} \cdot \mathrm{kg}^{-1}$ in roots, and from 28.9 to $91.6 \mathrm{mg} \cdot \mathrm{kg}^{-1}$ in the parts above the ground), whereas lead was present in the smallest amounts (from 0.09 to 0.36 $\mathrm{mg} \cdot \mathrm{kg}^{-1}$ in the roots, and from 0.15 to $0.53 \mathrm{mg} \cdot \mathrm{kg}^{-1}$ in the parts above the ground). The concentrations of the metals estimated in the dandelion biomass can be arranged as follows: $\mathrm{Zn}>\mathrm{Cu}>\mathrm{Ni}>\mathrm{Cd}>\mathrm{Pb}$ (Figure 2).

Many authors have demonstrated a significant increase in the levels of heavy metals in the biomass of plants in areas affected by traffic pollution (Czarnowska 1980, Bomze et al. 2007, Jankowska et al. 2007, Jankowski et al. 2015, Malinowska et al. 2015, Kowalczyk and Szulc 2017).

Regression analysis indicates that the concentrations of the trace elements estimated in the dandelion biomass increase significantly due to the increase in the amounts of these metals in the soil (Figure 3, Table 2). The values of the correlation coefficient $r$ shown in Table
2 indicate that the amounts of the metals in the roots are more strongly correlated with their amounts in the soil compared with the amounts of these elements in the aboveground parts of the plant despite the fact that the aboveground parts were characterized by higher root concentrations of these metals (Figure 2).

This correlation indicates the capacity of the common dandelion to take up metals not only through the roots but also through the leaves (Schreck et al. 2012). Jankowski et al. (2015) and Malinowska et al. (2015) demonstrated the capacity of plants growing in the vicinity of traffic routes to absorb heavy metals from the traffic dust deposited on leaf surfaces.

\section{CONCLUSIONS}

The soil heavy metal concentrations determined were the highest in the immediate vicinity of the roadway and decreased significantly with distance from the traffic route. The concentrations of studied elements in the dandelion biomass were significantly positive correlated with the soil metal concentrations. Regardless of the distance from the traffic route, dandelion plants accumulated larger amounts of heavy metals in the parts above the ground than in the roots.

The content of heavy metals in soils depends primarily on the abundance of the parent rock, weathering and soil-forming processes, and the human impact on their soil concentration are usually of secondary importance. For these reasons, irrespective of the sampling location, the soil was characterized by the highest concentrations of zinc, and the lowest of cadmium. The concentrations of the metals can be arranged as follows: $\mathrm{Zn}>\mathrm{Pb}>\mathrm{Cu}>\mathrm{Ni}>\mathrm{Cd}$.

Among the analysed metals, dandelion plants were found to contain the highest amounts of zinc and the lowest of lead. The concentrations of the estimated metals in the dandelion biomass can be arranged as follows: $\mathrm{Zn}>\mathrm{Cu}>\mathrm{Ni}>\mathrm{Cd}>\mathrm{Pb}$.

TABLE 2. Regression equations between contents of heavy metals in common dandelion roots and parts above ground and studied soil metal contents

\begin{tabular}{|c|c|c|c|c|}
\hline Dependent variable & Independent variable & Equation & $p$ & $r$ \\
\hline $\begin{array}{l}\mathrm{Zn} \text { in roots }\left(\mathrm{Zn}_{\mathrm{R}}\right) \\
\mathrm{Zn} \text { in parts above ground parts }\left(\mathrm{Zn}_{\mathrm{AG}}\right)\end{array}$ & $\begin{array}{l}\mathrm{Zn} \text { in soil } \\
\left(\mathrm{Zn}_{\mathrm{S}}\right)\end{array}$ & $\begin{array}{l}\mathrm{Zn}_{\mathrm{R}}=1.35 \mathrm{Zn}_{\mathrm{S}}+24.65 \\
\mathrm{Zn}_{\mathrm{AG}}=1.91 \mathrm{Zn}_{\mathrm{S}}+32.91\end{array}$ & $<0.01$ & $\begin{array}{l}0.77 \\
0.73\end{array}$ \\
\hline $\begin{array}{l}\mathrm{Cd} \text { in roots }\left(\mathrm{Cd}_{\mathrm{R}}\right) \\
\mathrm{Cd} \text { in parts above ground }\left(\mathrm{Cd}_{\mathrm{AG}}\right)\end{array}$ & $\begin{array}{l}\text { Cd in soil } \\
\left(\mathrm{Cd}_{\mathrm{S}}\right)\end{array}$ & $\begin{array}{l}\mathrm{Cd}_{\mathrm{R}}=1.71 \mathrm{Cd}_{\mathrm{S}}+0.27 \\
\mathrm{Cd}_{\mathrm{AG}}=1.94 \mathrm{Cd}_{\mathrm{S}}+0.37\end{array}$ & $<0.01$ & $\begin{array}{l}0.76 \\
0.72 \\
\end{array}$ \\
\hline $\begin{array}{l}\mathrm{Cu} \text { in roots }\left(\mathrm{Cu}_{\mathrm{R}}\right) \\
\mathrm{Cu} \text { in parts above ground }\left(\mathrm{Cu}_{\mathrm{AG}}\right)\end{array}$ & $\begin{array}{l}\mathrm{Cu} \text { in soil } \\
\left(\mathrm{Cu}_{\mathrm{S}}\right)\end{array}$ & $\begin{array}{l}\mathrm{Cu}_{\mathrm{R}}=1.35 \mathrm{Cu}_{\mathrm{S}}+24.65 \\
\mathrm{Cu}_{\mathrm{AG}}=1.91 \mathrm{Cu}_{\mathrm{S}}+32.91\end{array}$ & $<0.01$ & $\begin{array}{l}0.72 \\
0.69 \\
\end{array}$ \\
\hline $\begin{array}{l}\mathrm{Ni} \text { in roots }\left(\mathrm{Ni}_{\mathrm{R}}\right) \\
\mathrm{Ni} \text { in parts above ground }\left(\mathrm{Ni}_{\mathrm{AG}}\right)\end{array}$ & $\begin{array}{l}\mathrm{Ni} \text { in soil } \\
\left(\mathrm{Ni}_{\mathrm{S}}\right)\end{array}$ & $\begin{array}{l}\mathrm{Ni}_{\mathrm{R}}=1.35 \mathrm{Ni}_{\mathrm{S}}+24.65 \\
\mathrm{Ni}_{\mathrm{AG}}=1.91 \mathrm{Ni}_{\mathrm{S}}+32.91\end{array}$ & $<0.01$ & $\begin{array}{l}0.61 \\
0.56 \\
\end{array}$ \\
\hline $\begin{array}{l}\mathrm{Pb} \text { in roots }\left(\mathrm{Pb}_{\mathrm{R}}\right) \\
\mathrm{Pb} \text { in parts above ground }\left(\mathrm{Pb}_{\mathrm{AG}}\right)\end{array}$ & $\begin{array}{l}\mathrm{Pb} \text { in soil } \\
\left(\mathrm{Pb}_{\mathrm{S}}\right)\end{array}$ & $\begin{array}{l}\mathrm{Pb}_{\mathrm{R}}=1.35 \mathrm{PbS}_{\mathrm{G}}+24.65 \\
\mathrm{~Pb}_{\mathrm{AG}}=1.91 \mathrm{~Pb}_{\mathrm{S}}+32.91\end{array}$ & $<0.01$ & $\begin{array}{l}0.67 \\
0.56\end{array}$ \\
\hline
\end{tabular}



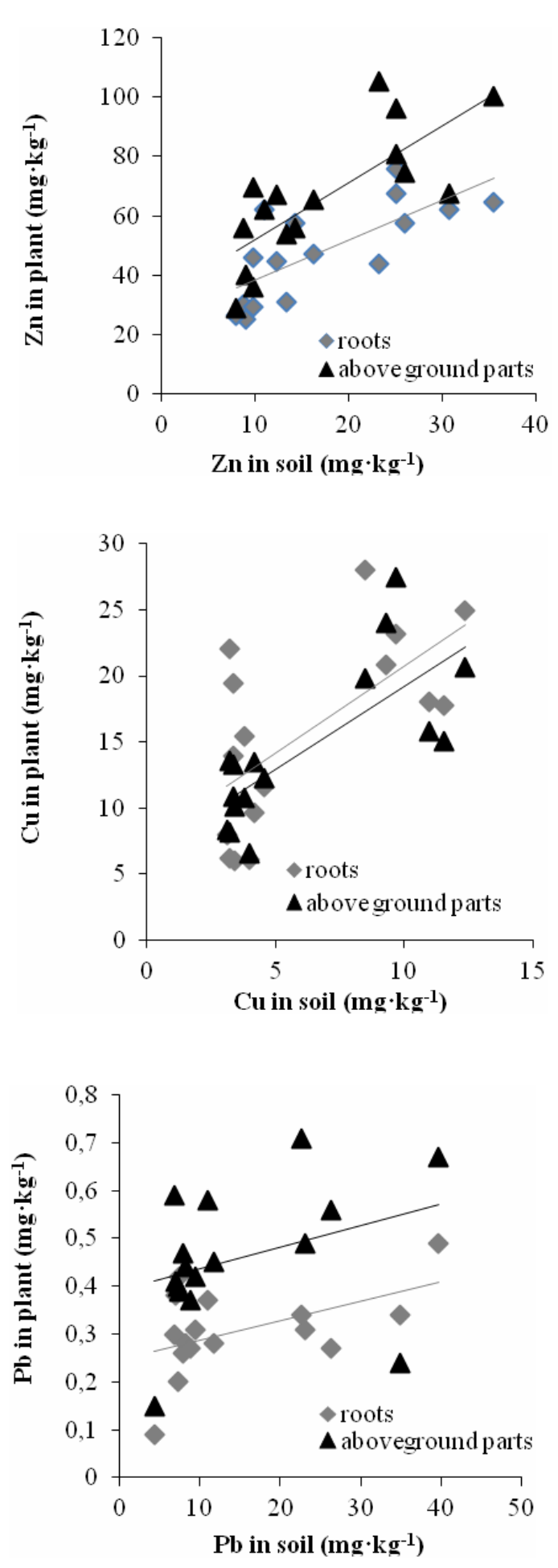

\section{REFERENCES}

Athanasopoulou A., Kollaros G., 2016. Heavy metal contamination of soil due to road traffic. American Journal of Engineering Research 5(12): 354-363.

Bomze K., Rutkowska B., Szulc W., 2007. Zawartość pierwiastków śladowych w mniszku pospolitym (Taraxacum officinale) w zależności od odległości od trasy komunikacyjnej. Roczniki Gleboznawcze - Soil Science Annual 58(3/4): 38-42.
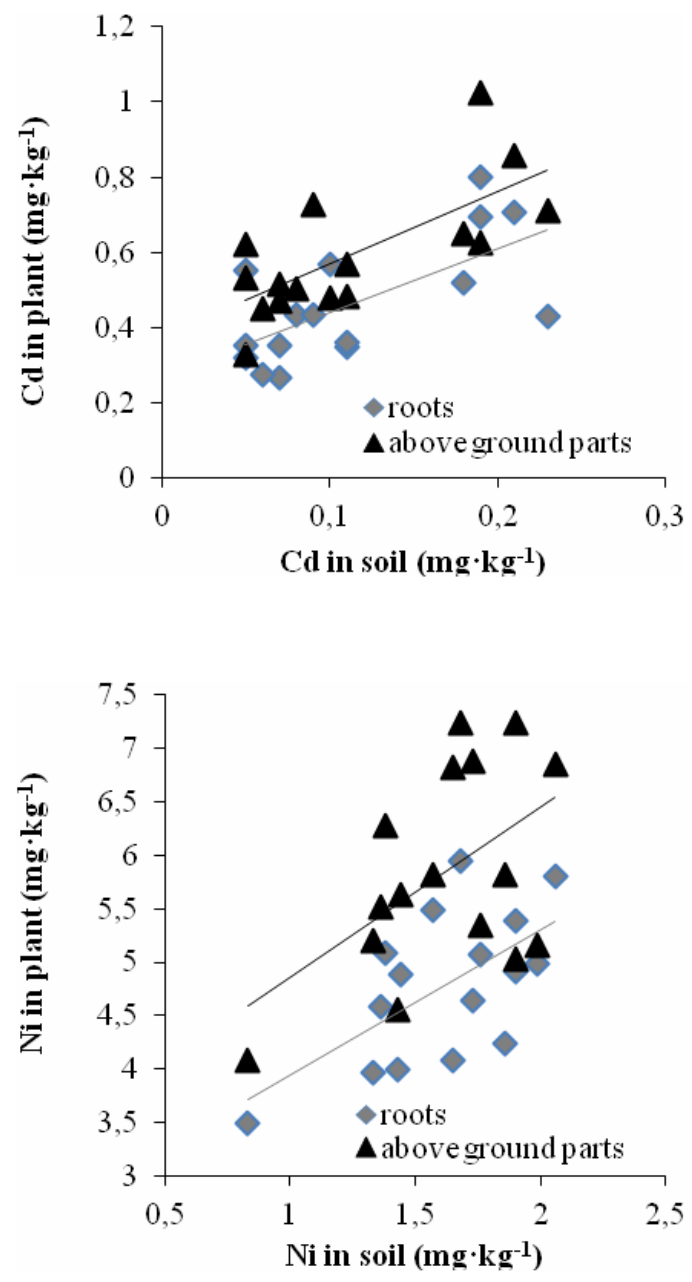

FIGURE 3. Relationship between common dandelion heavy metal biomass content and content of these metals in the studied soils

Czarnowska K., 1980. Akumulacja metali ciężkich w glebach, roślinach i niektórych zwierzętach na terenie Warszawy. Roczniki Gleboznawcze - Soil Science Annual 31(1): 77-116.

Czarnowska K., 1999. Metale ciężkie w glebach zieleńców Warszawy. Roczniki Gleboznawcze - Soil Science Annual 50(1/2): 31-39.

Czubaszek R., Bartoszuk K., 2011. Zawartość wybranych metali ciężkich w glebach w zależności od ich odległości od ulicy i sposobu użytkowania terenu. Civil and Environmental Engineering/Budownictwo i Inżynieria Środowiska 2: 27-34. 
Dmochowski D., Predecka A., Mazurek M., Pawlak A., 2011. Ocena zagrożeń związanych z emisją metali ciężkich w aspekcie bezpieczeństwa ekologicznego na przykładzie ogródków działkowych w aglomeracji miejskiej. Polski Przegląd Medycyny i Psychologii Lotniczej 3(17): 257-265.

Dzierżanowski K., Gawroński S.W., 2011. Analiza zawartości metali ciężkich w glebie i liściach mniszka lekarskiego w sąsiedztwie ruchliwej ulicy miejskiej przy użyciu przenośnego spektrometru XRF. Ochrona Środowiska i Zasobów Naturalnych 50: 202-211.

Jankowska J., Sosnowski J., Ciepiela G.A., Jankowski K., 2007. Zawartość ołowiu w wybranych gatunkach roślin dwuliściennych rosnących na użytkach zielonych w pobliżu trasy szybkiego ruchu. Ochrona Środowiska i Zasobów Naturalnych 30: 99-104.

Jankowski K., Ciepiela G.A., Jankowska J., Szulc W., Kolczarek R., Sosnowski J., Wiśniewska-Kadżajan B., Malinowska E., Radzka E., Czeluściński W., Deska J., 2015. Content of lead and cadmium in aboveground plant organs of grasses growing on the areas adjacent to a route of big traffic. Environmental Science and Pollution Research 22: 978-987.

Karczewska A., Kabała C., 2017. Analiza ryzyka środowiskowego jako nowa podstawa oceny stanu zanieczyszczenia gleb w polskim prawie. Roczniki Gleboznawcze - Soil Science Annual 68(2): 67-80.

Kaszubkiewicz J., Kawałko D., 2009. Zawartość wybranych metali ciężkich w glebach i roślinach na terenie powiatu Jeleniogórskiego. Ochrona Środowiska i Zasobów Naturalnych, 40: 177-189.

Komorowski A., Szulc W., 2017. Impact of traffic routes on the content of trace elements in soils in Warsaw agglomeration. Soil Science Annual 68(2): 87-92.
Kowalczyk A., Szulc W., 2017. Effect of traffic routes on the trace element concentration in plants in the Warsaw agglomeration. Soil Science Annual 68(2): 93-98.

Malinowska E., Jankowski K., Wiśniewska-Kadżajan B., Sosnowski J., Kolczarek R., Jankowska J., Ciepiela G.A., 2015. Content of zinc and copper in selected plants growing along a motorway. Bulletin of Environmental Contamination and Toxicology 95: 638-643.

Niesiobędzka K., Krajewska E., 2008. Metale ciężkie w układzie gleba-roślinność w środowisku wielkomiejskim. Ekotoksykologia w Ochronie Środowiska, PZIiTS, Oddział Dolnośląski, Wrocław: 265-270.

Schreck E., Foucault Y., Sarret G., Sobańska S., Cécillon L., Castrec-Rouelle M., Uzu G., Dumat C., 2012. Metal and metalloid foliar uptake by various plant species exposed to atmospheric industrial fallout: Mechanisms involved for lead. Science of the Total Environment 427/428: 253-262.

Sławiński J., Gołąbek E., Senderak G., 2014. Wpływ zanieczyszczeń komunikacyjnych na glebę i uprawną roślinności przydrożną. Inżynieria Ekologiczna 40: 137-144.

Świercz A., 2004. Rola biowskaźników w monitoringu zanieczyszczeń środowiska i rekultywacji terenów poprzemysłowych. [W:] Perspektywy rozwoju regionu w świetle badań krajobrazowych (Strzyż M. red.). Problemy Ekologii Krajobrazu PAEK, Kielce: 235-241.

Website $1 \mathrm{https}$ ://zdm.waw.pl/robi-sie/badania-i-analizy/analizaruchu-na-drogach

Website 2 https://www.google.pl/maps/@52.1613119,21. $048234,14.5 \mathrm{z} ? \mathrm{hl}=\mathrm{pl}$

Wei B., Yang L., 2010. A review of heavy metal contaminations in urban soils, urban road dusts and agricultural soils from China. Microchemical Journal 94: 99-107.

Received: January 12, 2018

Accepted: May 22, 2018

Associated editor: P. Hulisz

\section{Nagromadzenie wybranych metali ciężkich w glebach i mniszku pospolitym (Taraxacum officinale) w sąsiedztwie ulicy o dużym natężeniu ruchu}

Streszczenie: Wykonane badania miały na celu określenie zawartości wybranych pierwiastków śladowych w glebie oraz w częściach nadziemnych i podziemnych mniszka pospolitego w zależności od odległości od ciągu komunikacyjnego. Badania prowadzono na terenie Warszawy w okolicy jednej z głównych ulic w dzielnicy Ursynów. Próbki do badań pobierano z warstwy $0-25 \mathrm{~cm}$ z miejsc położonych bezpośrednio przy jezdni oraz w odległości 30, 60 oraz 300 m od jej krawędzi. Zawartości $\mathrm{Pb}, \mathrm{Ni}, \mathrm{Cu}, \mathrm{Zn}$ i Cd oznaczono w glebie metodą ASA po ekstrakcji w $\mathrm{HCl}$ o stężeniu $1 \mathrm{~mol} \cdot \mathrm{dm}^{-3}$ oraz w częściach nadziemnych i korzeniach mniszka pospolitego po mineralizacji na mokro w mieszaninie kwasów $\mathrm{HNO}_{3}$ i $\mathrm{HClO}_{4}$. Na podstawie uzyskanych wyników wykazano, że zawartości badanych metali zarówno w glebie, jak i w biomasie rośliny testowej były największe bezpośrednio przy krawędzi jezdni i zmniejszały się istotnie wraz z odległością od jezdni. Zależność taka wskazuje na istotny wpływ transportu drogowego na zawartości metali ciężkich w środowisku graniczącym z ciągiem komunikacyjnym. Wykazano również, że mniszek pospolity gromadzi większe ilości metali ciężkich w części nadziemnej niż w korzeniach. Stwierdzono, iż zawartości metali ciężkich w biomasie mniszka pospolitego są istotnie dodatnio skorelowane z zawartościami tych pierwiastków w glebie.

Słowa kluczowe: metale ciężkie, transport drogowy, gleby miejskie, roślinność przydrożna, zanieczyszczenie gleby 